$m^{\text {ten }}$ Grades des Coefficientensystems. Wollte man nun aus den Quadraten dieser Quotienten das arithmetische Mittel nehmen, so würde man zu kaum ausführbaren Rechnungen kommen und ein Resultat erhalten, welches zu der Summe der Quadrate der übrig bleibenden Fehler in keiner näheren Beziehung stände. Nimmt man dagegen einen Mittelwerth in ähnlicher Weise, wie ihn Jacobi von den zu den einzelnen Combinationen gehörigen Werthen der Unbekannten gebildet hat, so erhält man eine einfache Beziehung. Eine Uebereinstimmung findet dann auch darin statt, dass die Divisoren in beiden Fällen dieselben sind, nämlich die Determinanten des Coefficientensystems. Man wird also den gesuchten Mittelwerth in der Weise bilden, dass man die Summe der Quadrate der sämmtlichen Dividenden durch die Summe der Quadrate der Divisoren der $n \cdot\left(\begin{array}{c}n \\ m\end{array}\right)$ Bruchausdrücke dividirt. Es ist also nur zu bestimmen, welche von o verschiedene Dividenden und Divisoren vorhanden sind, gleichviel wie sie zusammen gehören. Als Dividenden erscheinen nothwendig sämmtliche Determinanten des Constantensystems und $z$ war jede $(\dot{m}+1)$ mal; denn irgend eine solche Deter. minante wird erhalten, indem man in irgend eine von $(m+1)$ Gleichungen die Auflösung der übrigen $m$ Gleichungen einsetzt. Ausserdem werden noch Dividenden erhalten, die $=0$ sind, die nämlich entstehen, indem man in eine von $m$ Gleichungen die Auflösung dieser $m$ Gleichungen einsetzt. Als Dividend des gesuchten Mittelwerthes erhält man somit $(m+I)$ mal die Summe der Quadrate der sämmtlichen Determinanten $(m+1)^{\text {ten }}$ Grades des Constantensystems.

Divisor wird jede Determinante des Coefficientensystems und zwar kommt jede derselben $n$ mal als Divisor vor, weil die Auflösung von irgend $m$ Gleichungen in sämmtliche $n$ Gleichungen eingesetzt wird. Der Divisor des gesuchten Mittelwerthes ist somit die $n$ fache Summe der Quadrate der Determinanten $m^{\text {ten }}$ Grades des Coefficientensystems.

Bezeichnet man also die Summe der Quadrate der Determinanten des Constantensystems mit $\left[D^{2}\right]$, die entsprechende Summe für das Coefficientensystem mit $\left[\Delta^{2}\right]$, so erhält man das mittlere Fehlerquadrat

Poppelsdorf 1897 März 20.
$F^{2}=\frac{(m+1)\left[D^{2}\right]}{n\left[\Delta^{2}\right]}$
Der Ausdruck $\frac{\left[D^{2}\right]}{\left[\Delta^{2}\right]}$ ist nun gleich der Summe der Quadrate der übrig bleibenden Fehler*), wenn man den Unbekannten die durch die Methode der kleinsten Quadrate bestimmten Werthe giebt. Man hat also

$$
F^{2}=\frac{m+1}{n}\left(\varphi_{1}^{2}+\varphi_{2}^{2}+\cdots+\varphi_{n}^{2}\right)
$$

Der Ausdruck für $F^{2}$ weicht also von dem Gauss'schen nur durch den Zahlenfactor ab. Wenn $m$ nur um r kleiner ist als $n$, so stimmen beide Werthe uiberein.

Obige Bestimmung des mittleren Fehlers ist der Jacobi' schen Bestimmung der Unbekannten ganz analog. Wenn nun die eine für rationell gehalten wird, so wird man auch die andere als solche gelten lassen müssen. Nun wird aber die letztere thatsächlich allgemein angewandt; denn die Jacobi'schen Werthe der Unbekannten sind nichts anderes als die Gauss'schen, explicite dargestellt. Es wird also wohl gegen obige Herleitung des mittleren Fehlers nichts Wesentliches eingewendet werden können.

Wenn $n>m+1$, so ist der obige Werth stets grösser als der Gauss'sche. Und wenn, was ja in der Regel der Fall ist, $n$ beträchtlich grösser ist als $m+1$, so ist auch der Unterschied der beiden Fehlermittel bedeutend, derart, dass das eine ein Mehrfaches des anderen ist. Man möchte nun über diese Verschiedenheit des constanten Factors, während der veränderliche Theil des Ausdrucks genau derselbe bleibt, sich etwas nähere Rechenschaft geben können. Allein hierzu scheint es an jedem Anhaltspunkt zu fehlen. Bekanntlich befindet sich der Mathematiker, sobald er an die Lösung des Problems der Fehlerausgleichung herantritt, auf einem eigenthümlich unsicheren Boden. Schon das auf diesem Gebiet häufig angewandte, in der. Mathematik aber sonst nicht gebräuchliche Wort »plausibel « deutet hierauf hin. Nun, was die Plausibilität betrifft, dürfte meine Herleitung und somit auch das Resultat derselben nichts $\mathrm{zu}$ wünschen übrig lassen. Vielleicht würde bei häufig wiederholter Anwendung mèner Formel auf praktische Fälle die Erfahrung weitere Aufklärung geben.

Dr. W. Veltmann.

*) Veltmann, Ausgleichung der Beobachtungsfehler. Marburg I886. S. 33.

\title{
Comparison of Meridian Circle Observations at Berlin and Mount Hamilton.
}

\section{By R. H. Tucker.}

The publication of the extensive series of observations by Dr. Kuistner, in the Astronomische Nachrichten, affords an opportunity of comparison with the series lately completed at this observatory.

The comparison presents some features of special interest, in its relation to the system of the Berliner Jahrbuch, upon which each series has been based.

Since the Lick Observatory results will soon be published in full, it does not appear necessary to anticipate their appearance, by printing any part of them here; but the details of the comparison can be given briefly.

The methods of observation and reduction are similar in the two sets. Dr. Küstner has given so clear and exhaustive a discussion of the Berlin observations, that no further reference to the details of his work need be made. The Declinations determined bere are differential, a 
list of Equatorial stars, between $+15^{\circ}$ and $-10^{\circ}$, having been adopted, both for the Equator points; and the clock corrections. All transits were observed by chronograph; the circumpolar stars were obtained as far as possible at both culminations; and zenith stars were observed facing both North and South, having been used for the determination of bisection error. Eight fundamental stars were, in general, observed each night, and six for azimuth.

For the comparison three groups of B. J. stars are available. First, 45 circumpolars, of which 32 have been observed at both culminations, there being an average of I 2 observations for a culmination, or of 2 I per star. Second, 14 zenith stars, observed from 4 to 12 times each, and reduced with the Equatorial fundamentals. Third, 78 clock stars, including 62 of the Hauptsterne and 16 Zusatzsterne, with an average of 15 observations.

The determinations are in general distributed between two positions of the instrument, clamp, or fixed circle, East and West.

In the comparison which follows, the mean difference is given between each set and the Jahrbuch, and between the two sets; each being followed by the average of the differences, taken without regard to sign.

With respect to accidental error, the Berlin observations have, as a rule, greater intrinsic strength in both coordinates; the transits being over 15 threads, as compared with 7 ; and the declinations observed in four positions, as compared with two.

Declinations of the circumpolar group (45 stars):

$$
\begin{array}{lll}
\text { K. - B. J. } & -0.104 \pm 0.25 \\
\text { T. - B. J. } & -0.003 \pm 0.26 \\
\text { T. - K. } & +0.10 \quad \pm 0.25
\end{array}
$$

It would appear that the respective errors of the two series, and of B.J. are nearly the same. It is a matter of general experience, that the probable error, given by a comparison of two distinct series, will be greater than that which results from the discussion of either separately. The explanation is somewhat obscure, but there are probably systematic errors, affecting determinations which are technically differential in character.

Adopting in the above, as systematic, the difference $\mathrm{T}$. $-\mathrm{K}$. +o"ro, there results the p. e. of $\Delta$ from one star \pm 0.20 . Without distinction of weights, the p.e. of each would be \pm 0 " I 4 .

In the right ascensions of the circumpolar group, there is for each series a decided deviation from B. J., $\mid$ is 1895.0 . Lick Observatory, University of California, r897 Jan. 30. which may be due to personal equation in transits. For the observations made here, there is no difference between the results at the two culminations.

Right ascension, 36 stars (omitting I H. Drac.) :

$$
\begin{aligned}
& \text { K. - B.J. } \quad+0.011 \sec \delta \pm 0.027 \sec \delta \\
& \text { T. - B. J. } \quad-0.008 \sec \delta \pm 0.022 \sec \delta \\
& \text { T. - K. } \quad-0.020 \sec \delta \pm 0.020 \sec \delta
\end{aligned}
$$

With the systematic difference, T. - K. - - o.o 20 sec $\delta$, the p. e. of $\Delta$ from one star is $\pm 0.007 \mathrm{sec} \delta$; whence the p. e. of each series would be $\pm 0.005 \mathrm{sec} \delta$.

For the group of zenith stars:

$$
\begin{array}{lrrr}
\text { K. - B. J. } & +0.005 \pm 0.027 & 0.00 \pm 0.29 \\
\text { T. - B. J. } & -0.027 \pm 0.040 & -0.1 \text { I } \pm 0.44 \\
\text { T. - K. } & -0.032 \pm 0.032 & -0.11 \pm 0.24
\end{array}
$$

The systematic difference in RA. between the two sets of observations is evident, all of the differences having the same sign. Adopting as systematic, T. $-\mathrm{K}$. - 0.032 and $-O$. I I, the p.e. of $\Delta$ from one star is

$$
\pm 0.016= \pm 0.013 \sec \delta \text { and } \pm 0.22 \text {; }
$$

whence each would have the p. e. $\pm 0.009 \sec \delta$ and \pm 0.15 .

In the Equatorial group the results for Hauptsterne and Zusatzsterne do not differ essentially. For 7.8 stars common to both sets :

$$
\begin{array}{lrr}
\text { K. }- \text { B. J. } & -0.005 \pm 0.014 & -0.01 \\
\text { T. }- \text { B. J. } & 0.000 \pm 0.19 \\
\text { T. }- \text { K. } & +0.005 \pm 0.023 & +0.01 \pm 0.28 \\
\end{array}
$$

The indications are that the error of $\mathrm{K}$. is smaller than that of T., and that B. J. lies between them. The comparison T. - K. gives the p.e. of $\boldsymbol{\Delta}$ for one star,

$$
\pm 0.0148 \text { and } \pm 0.17 \text {. }
$$

With equal distribution, there would be for each the p. e. \pm 0 soro and \pm 0 "I 2.

The comparison may presumably serve as a better criterion of the B.J. places, than either series would alone. In 137 stars included, there is but one, in which the difference T. - B. J. amounts to $1^{\prime \prime}$ in declination; and the result for this star, Gr. $145^{\circ} 8^{\mathrm{h}} 26^{\mathrm{m}}, \mathrm{T}$. - B. J. $+\mathrm{I}^{\prime \prime} \cdot \mathrm{r}$, is entirely confirmed by Dr. Küstner. The largest remaining in declination are +0.83 and -0.83 ; and there are no differences as large between the two series of observations.

The places of the Equatorial stars, observed here, have been reduced so as to be independent of the use of the star as a fundamental. The mean epoch of this series

\section{R. H. Tucker.}

\title{
Meridian Circle Observations of Comparison Stars
}

\author{
for Comets 1895 II (Swift), 1896 III and 1896 VI (Brooks 1889 V).
}

\section{By R. H. Tucker.}

The first ten stars of the following list have been determined, in order to furnish more exact places for the observations of Comet 1896 III; for which the definitive orbit is to be computed by Prof. Aitken:
The star places may be of service to those, by whom the original observations were made.

The last two stars have been used here, with Brooks' Comet, 1896 VI, and Swift's Comet, 1895 II, respectively. 